\title{
Adhesive cards for monitoring flying insects in a neonatal intensive care unit in a hospital in the Triângulo Mineiro - Minas Gerais - Brazil
}

\author{
Afonso Pelli* \\ Adriana Gonçalves Oliveira \\ Paulo Roberto da Silva \\ Henrique Borges Kappel \\ Instituto de Ciências Biológicas e Naturais, Universidade Federal do Triângulo Mineiro \\ Avenida Frei Paulino, 30, CEP 38025-180, Uberaba - MG, Brasil \\ *Autor para correspondência \\ apelli.oikos@dcb.uftm.edu.br
}

Submetido em 10/03/2011

Aceito para publicação em 27/10/2011

\section{Resumo}

Placas adesivas para o monitoramento de insetos voadores em uma unidade intensiva neonatal em um hospital no Triângulo Mineiro - Minas Gerais - Brasil. Utilizando-se placas adesivas coloridas, foram capturados 1.016 insetos voadores em Unidade de Terapia Intensiva Neonatal de um hospital. A Ordem Homoptera foi a mais frequente $(84,7 \%)$. Foi demonstrada atração diferenciada pela cor da placa. Insetos são vetores mecânicos de patógenos, e este trabalho demonstra a necessidade e a relevância do controle em ambientes hospitalares.

Palavras-chave: Insetos alados, Infecção hospitalar, Saúde pública

\section{Abstract}

Using adhesive colored cards, 1,016 flying insects were captured in a neonatal intensive care unit of a hospital. Homoptera were the most common (84.7\%), and attraction based on card color was demonstrated. Insects are mechanical vectors of pathogens, and this work demonstrates the necessity and the relevance of insect control in hospital environments.

Key words: Hospital infection, Public health, Winged insects

In Brazil, many groups of insects are important in medicine and human hygiene, such as houseflies (Musca domestica Linnaeus, 1758), blowflies (Calliphoridae Diptera), flesh flies (Sarcophagidae - Diptera), horseflies (Tabanidae - Diptera), midges (Ceratopogonidae Diptera), mosquitoes (Culicidae - Diptera), Heteroptera (bedbugs), Siphonaptera (fleas) and Anoplura (lice). They may directly interact with humans, or indirectly interact with them due to their affinities with feces and decomposing organic material, thereby being potential vectors of infectious agents (PRADO et al., 2002; DA COSTA et al., 2006; PELLI et al., 2007a; 2007b; 2008), 
especially for patients in intensive critical care units (DANCER, 1999). Due to the difficulty of monitoring and controlling these organisms, insects can move between different environments and hospital beds, making them mechanical vectors of microorganisms and causing infections in hospitals (CHADEE; MAITRE, 1990; COSTA et al., 2006). The purpose of this study was to learn more about the fauna of flying insects in the neonatal intensive care unit of the hospital at the Federal University of Triângulo Mineiro. Collections were made using four adhesive cards (two blue and two yellow), measuring $24.5 \times 10 \mathrm{~cm}$, in October of 2003. The sticky cards were placed near lights for a period of one week. The plates were then removed, preserved with PVC film, and the insects were identified using a stereomicroscope and a taxonomic key (BORROR; DWIGHT, 1988). The results were described using descriptive statistics, and were analyzed by the Chi square test using Statistic 7.0.

We captured a total of 1,016 insects, of which $38 \%$ which caught on the yellow cards and $62 \%$ on the blue cards. Homoptera were the most common insects captured $(84.7 \%)$, and the proportion of these insects captured on the blue cards was higher than those collected on the yellow cards (Chi-square 60.06; $\mathrm{p}<0.05$ ). The second most common order was Hymenoptera that, unlike Homoptera, were more abundant on yellow cards (Chi-square 16.23; $\mathrm{p}<0.05)$. The other captured orders were Diptera (5.6\%), Heteroptera (3.3\%), Coleoptera (2.2\%) and Orthoptera $(0.8 \%)$, but the numbers collected for these groups were not significant relative to card color. As in other studies, (MELO et al., 2001; RODRIGUES-NETTO et al., 2002; MACEDO et al., 2003; SILVEIRA et al., 2005), the attraction of certain species to specific card colors demonstrates the complexity of the dynamics of the targeted insects. The statistical difference in the groups Homoptera and Hymenoptera, in relation to card color, suggests the possibility that these groups should be monitored separately using blue (Homoptera) and yellow (Hymenoptera) cards.

The results point to the need to implement policies to monitor and control insects in this hospital. According to the Commission of Hospital Infection Control (HICC), from this hospital, insects are controlled with chemicals when requested or when infestations are observed, something that happens (on average) every two weeks.
The data also point to the need to implement new methods of monitoring and control based on different assumptions and methodologies, because what is currently used is ineffective. The adhesive cards used in this study were effective in monitoring the orders Homoptera and Hymenoptera, which are known to be responsible for the transmission of pathogenic microorganisms, especially those that cause fungal and bacterial infections (DA COSTA et al., 2006, KONTSEDALOV et al., 2008, HUGHES et al., 2011).

Screens and windows in the hospital should be checked for the presence of hiding insects and insect eggs, as well as other hiding places, such as cracks, electric cable drivers, electrical outlets, drains and closets. The HICC maintains a key role in promoting programs not only in cleaning and sanitation, but also plans and adopts measures related to the control of both insects and pathogens related to hospital infections.

In conclusion, this work demonstrates that single strategies of control are not effective for insects in hospitals because the diversity of species is high. Therefore, it is necessary, before taking control measures, to evaluate the weed species to verify their temporal and spatial distribution. Moreover, the composition of the HICC should be revised to include a professional that is well educated in environmental issues because these insects play an important role not only in public health, but also in the hospital. The monitoring of insects can prevent the mechanical transmission of nosocomial pathogens and risk factors in an intensive treatment ward, which is caused by the groups studied, especially Homoptera and Hymenoptera.

\section{Acknowledgements}

The authors are grateful to FAPEMIG (Foundation of Research of the State of Minas Gerais) by the exchange of scientific initiation grant and Biocontrol - Methods of Pest Control Ltd, by transferring the adhesive cards.

\section{References}

BORROR, D. J.; DWIGHT, M. D. Introdução ao estudo dos insetos. São Paulo: Edgard Blucher LTDA, 1988. 654 p. 
CHADEE, D. D.; MAITRE, A. L. Ants: potential mechanical vectors of hospital infections in Trinidad. Transactions of the Royal Society of Tropical Medicine and Hygiene, London, v. 84, n. 2, p. 297, 1990.

DA COSTA, S. B.; PELLI, A.; DE CARVALHO, G. P.; OLIVEIRA, A. G.; DA SILVA, P. R.; TEIXEIRA, M. M.; MARTINS, E.; TERRA, A. P.; RESENDE, E. M.; DE OLIVEIRA, C. C. H. B.; DE MORAIS, C. A. Ants as mechanical vectors of microorganisms in the School Hospital of the Universidade Federal do Triângulo Mineiro. Revista da Sociedade Brasileira de Medicina Tropical, Uberaba, v. 9, p. 527-529, 2006.

DANCER, S. J. Mopping up hospital infection. Journal of Hospital Infection, London, v. 43, p. 85-100, 1999.

HUGHES, D. P.; ANDERSEN, S.; HYWEL-JONES, N. L.; HIMAMAN, W.; BILLEN, J.; BOOMSMA, J. J. Behavioral mechanisms and morphological symptoms of zombie ants dying from fungal infection. BMC Ecology, London, v. 11, p. 13. 2011.

KONTSEDALOV, S.; ZCHORI-FEIN, E.; CHIEL, E.; GOTTLIEB, Y.; INBAR, M.; GHANIM, M. The presence of Rickettsia is associated with increased susceptibility of Bemisia tabaci (Homoptera: Aleyrodidae) to insecticides. Pest Management Science, Malden, v. 8, p. 789-92, 2008.

MACEDO, N.; BOTELHO, P. S. M.; BARBOSA, V.; DURIGAN, A. M. P. R. Monitoramento de adultos de cigarrinha da raiz, Mahanarva fimbriolata, em cana-de-açúcar, através de armadilha adesiva modelo biotrap-biocontrole. Métodos de Controle de Pragas, São Paulo, v. 8, p. 13-14, 2003.

MELO, L. A.; MOREIRA, A. N.; DA SILVA SILVEIRA, F. A. N. Armadilha para monitoramento de insetos. Comunicado Técnico da Embrapa Meio Ambiente, Jaguariúna, v. 1, n. 7, p. 1-4, 2001.
PELLI, A.; KAPPEL, H. B.; OLIVEIRA, A. G.; SILVA, P. R.; DOURADO, P. L.; BATAUS, L. M. Characterization of a Nocardia sp. isolated from an insect (moth-fly) captured in a university hospital. Journal of Hospital Infection, London, v. 67, p. 393-396, $2007 \mathrm{a}$.

PELLI A, SILVA MA, SARMENTO FR, MARTINS E, MATA AS, DOMINGUES MA, RAMIREZ LE. Parâmetros populacionais para Triatoma sordida Stal, 1859, o vetor mais frequente da doença de Chagas no Triângulo Mineiro (Heteroptera, Triatominae). Revista da Sociedade Brasileira de Medicina Tropical, Uberaba, v. 40, p. 1-4, 2007b.

PELLI, A.; BARBOSA, F. A. R.; TAYLOR, E. Samea multiplicalis (Guenée, 1854) (Lepidoptera, Pyralidade): a potential agent in the biological control of Salvinia molesta DS Mitchell (Salvineaceae). Acta Limnologica Brasiliensia, Botucatu, v. 20, p. 119-123, 2008. PRADO, M. A.; PIMENTA, F. C.; HAYASHID, M.; SOUZA, P. R.; PEREIRA, M. S.; GIR, E. Enterobactérias isoladas de baratas (Periplaneta americana) capturadas em um hospital brasileiro. Revista Panamericana de Salud Pública, Washington, v. 11, p. 93-98, 2002.

RODRIGUES NETTO, S. M.; CAMPOS, T. B.; ISHIMURA, I. Estudo da eficiência de armadilhas adesivas na atratividade de mosca-das-frutas Anastrepha spp. e Ceratitis capitata Wied. (Diptera, Tephritidae) em cultura orgânica de maracujá doce (Passiflora alata curtis, Passifloraceae). Instituto Biológico de São Paulo, São Paulo, v. 3, p. 32, 2002.

SILVEIRA, O. T.; ESPOSITO, M. C.; SANTOS, J. N.; GEMAQUE, F. E. Social wasps and bees captured in carrion traps in a rainforest in Brazil. Entomological Science, Kyoto, v. 8, p. 33-39, 2005. 